\title{
Recent contrasting behaviour of mountain glaciers across the European High Arctic revealed by ArcticDEM data
}

\author{
Jakub Małecki ${ }^{1}$ \\ ${ }^{1}$ Cryosphere Research Group, Adam Mickiewicz University, Poznań, Poland \\ Correspondence to: Jakub Małecki (malecki.jk@gmail.com)
}

5

\begin{abstract}
Small land-terminating mountain glaciers are a widespread and important element of Arctic ecosystems, influencing local hydrology, microclimate, and ecology, among others. Due to little ice volumes, this class of ice masses is very sensitive to climate warming, the latter of which is extremely well manifested in the European sector of the Arctic, i.e. in the Barents

10 Sea area. Archipelagos surrounding the Barents Sea, i.e. Svalbard (SV), Novaya Zemlya (NZ), and Franz Josef Land (FJ), host numerous populations of mountain glaciers, but their response to recent strong warming remains understudied in most locations. This paper aims to obtain a snapshot of their state by utilizing high-resolution elevation data (ArcticDEM) to investigate the recent (ca. 2011-2017) elevation and volume changes of 382 small glaciers across SV, NZ, and FJ. The study concludes that many mountain glacier sites across the Barents Sea have been in a critical imbalance with the recent climate

15 and might melt away within the coming several decades. However, deviations from the general trend exist, e.g. a cluster of small glaciers in north SV experiencing thickening. The findings reveal that near-stagnant glaciers might exhibit contrasting behaviours (fast thinning vs. thickening) over relatively short distances, being a challenge for climate models, but also an opportunity to test their reliability.
\end{abstract}

\section{Introduction}

The Arctic holds nearly a half of the global area and volume of glacier ice outside of ice sheets (Farinotti et al., 2019) and has been warming faster than other regions over the past decades (Screen and Simmonds, 2010). Recent progress in large-scale glacier mass balance studies, utilizing climate modelling, satellite altimetry, gravimetry and photogrammetry, fundamentally improved our knowledge on the general trends of glacier decay in the Arctic and the contribution of its ice masses to the global sea-level rise (e.g. Moholdt et al., 2012; Box et al., 2018; Noël et al., 2018; Wouters et al., 2019; Hugonnet et al., 2021). However, these general observations might have a limited use over smaller glaciers within dynamic topography due to the insufficient spatial resolution of the aforementioned techniques, leaving them with little reliable data in large-scale assessments.

Small $\left(<30 \mathrm{~km}^{2}\right)$ land-terminating ice masses (hereafter termed 'mountain glaciers') are the most widespread and numerous class of glaciers north of the Arctic circle, very vulnerable to climate warming due to low ice volumes and limited vertical 
30 extents. They commonly exhibit very low horizontal and vertical ice velocities, resulting from predominantly cold thermal regimes and low ice thickness, so their elevation changes might closely reflect the climate-driven point mass balance, only little modified by ice dynamics (e.g. Melvold and Hagen, 1998; Nutall and Hodgkins, 2005; Hambrey et al., 2005; Hagen et al., 2005). Therefore, studying arctic mountain glaciers might not only inform about fluctuations of their remaining volume but also provide a pieco of valuable proxy information about the state of climate over remote areas. This task is important for broadening our understanding of the possible responses of the cryosphere to climate warming, particularly in areas experiencing very fast changes, e.g. in arctic Europe.

The European sector of the Arctic surrounding the Barents Sea has been nicknamed 'the arctic warming hotspot' by Lind et al. (2018) due to the severe climate and oceanic warming and rapid retreat of sea ice it has been experiencing (e.g. Årthun et al., 2012; Comiso and Hall, 2014; Kohnemann et al., 2017). These strong shifts potentially exposed mountain glaciers of the

40 nearby archipelagos to increased melt, i.e. in Svalbard (SV), Novaya Zemlya (NZ) and Franz Josef Land (FJ). The available evidence from SV, the best studied of these regions, clearly shows that over the past decades mountain glaciers at several sites have been losing mass at fast rates and many of them have been experiencing accelerating thinning at high elevations (e.g. Kohler et al., 2007; James et al., 2012; Małecki 2016; Schuler et al., 2020).

Although mountain glaciers are likely the first to disappear from the rapidly warming Arctic, little detailed information on their recent state exists for most locations across the Barents Sea islands and not much is known about the impact the recent warming had on their mass balance. This study focuses on recent elevation changes among mountain glaciers across SV, NZ and FJ over the period ca. 2011-2017. Its objectives are to: (i) define the baseline style of the recent behaviour of mountain glaciers and detect anomalies; (ii) to investigate how common and how fast the high-elevation thinning has become across the Barents Sea area; and (iii) to estimate the future lifespan of mountain glaciers and detect sites where these are critically endangered by climate warming.

\section{Study area}

\subsection{Climatology of the Barents Sea area}

The Barents Sea is under a strong influence of warm Atlantic waters, particularly to the west (e.g. West Spitsbergen Current) and south (e.g. North Cape Current)(Fig. 1a), making the climate of these two sectors the mildest (Figs. 1b and 1c) and humid

55 (Fig. 1d). For this reason, waters west off SV and southwest off $\mathrm{NZ}$ are free of sea ice even during the winter (Fig. 1e). During summer seasons the Barents Sea is typically ice-free, except for low sea ice concentration around FJ (Fig. 1f), where the atlantic influence is reduced, making climate the coolest and driest. 

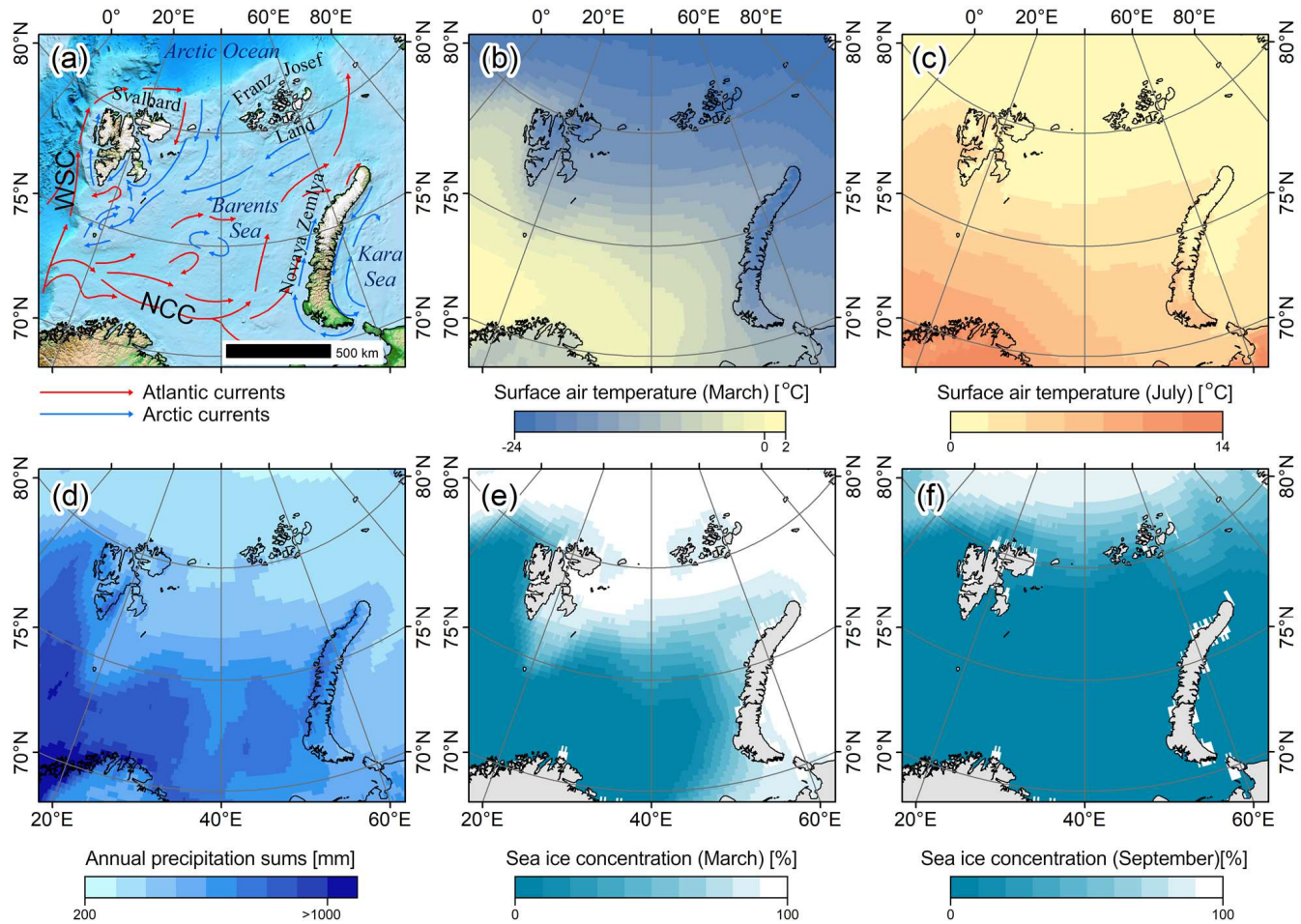

Figure 1 (a) Topography of the Barents Sea area and transport of atlantic water (red arrows) and arctic water (blue arrows) after the Institute of Marine Research in Bergen, Norway. WSC - West Spitsbergen Current; NCC - North Cape Current. (b-f) ERA5 1981-2010 climatology for the Barents Sea area (b March near-surface air temperature, c July near-surface air temperature, $d$ annual precipitation sums, e sea ice concentration in March, $f$ sea ice concentration in September).

Over the past decades, the entire Barents Sea area has been experiencing strong ocean and atmospheric changes, or Atlantification. Instrumental records indicate heat inflow from the Atlantic to the Arctic Ocean via the West Spitsbergen Current has been increasing (Piechura and Walczowski, 2009; Walczowski and Piechura, 2011), contributing to strong sea ice decline over the area (Årthun et al., 2012; Onarheim et al., 2014; Barton et al., 2018). Concurrently, mean sea surface temperature across the Barents Sea increased over the period 1981-2012 (Comiso and Hall, 2014). A strong positive trend in annual surface air temperature exceeding $1{ }^{\circ} \mathrm{C} /$ decade was reported for some sites, accompanied by an even stronger warming rate exceeding $3{ }^{\circ} \mathrm{C} /$ decade during winter months, particularly around SV and NZ (e.g. Isaksen et al., 2016; Kohnemann et al., 2017; Lind et al., 2018; Wawrzyniak and Osuch, 2020; Nordli et al., 2020; Dahlke et al., 2020). 

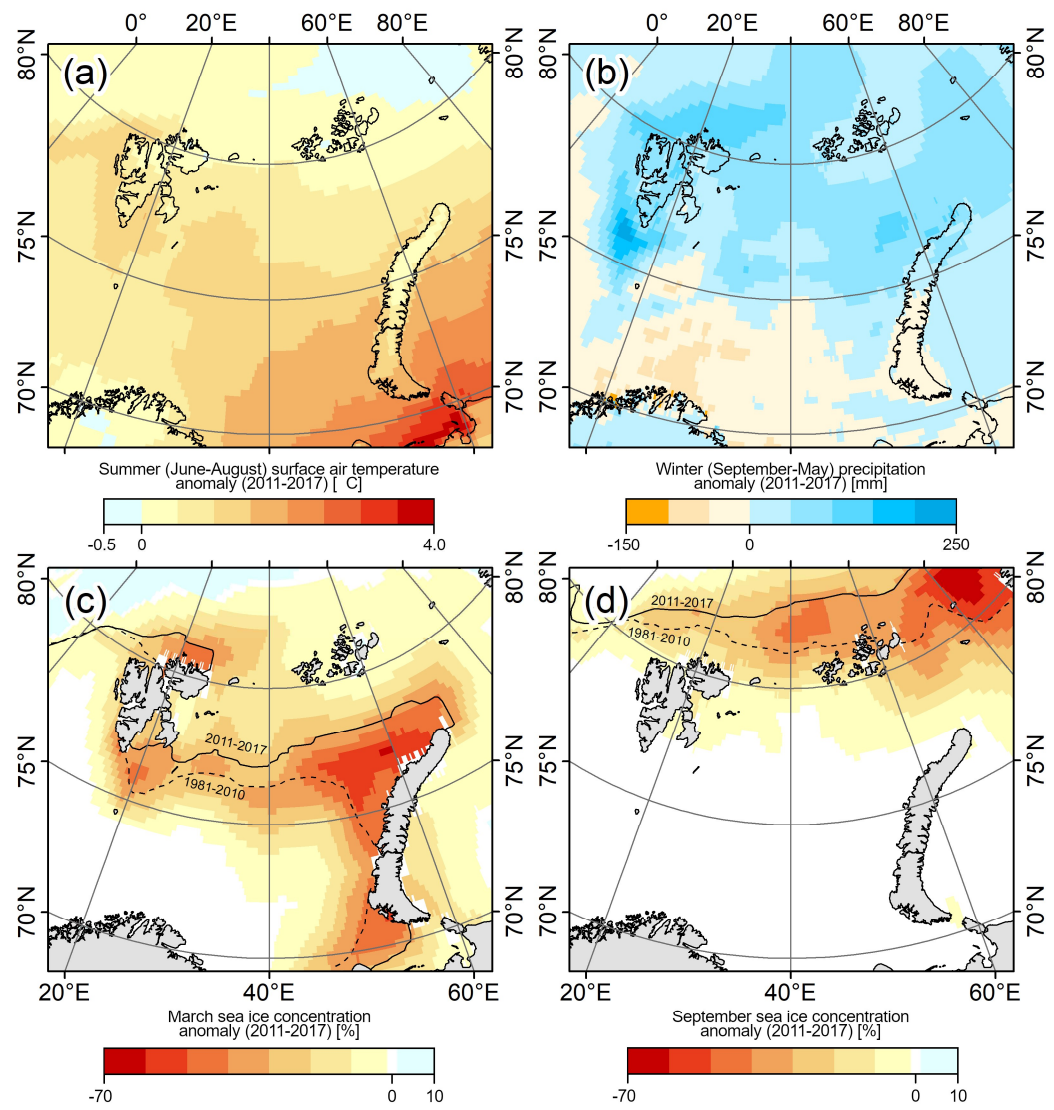

Figure 2 The 2011-2017 anomalies of selected climate variables from the ERA5 reanalysis in reference to the period 1981-2010. (a) Summer (June-August) near-surface air temperature anomaly. (b) Winter (September-May) precipitation anomaly. (c) March sea ice concentration anomaly. (d) September sea ice concentration anomaly. Dashed and solid black lines in $\mathrm{c}$ and $\mathrm{d}-\mathbf{5 0} \%$ sea ice concentration extent for 1981-2010 and 2011-2017, respectively.

According to the ERA5, a global climate reanalysis with a grid cell size of ca. 7 x $28 \mathrm{~km}$ at $75^{\circ} \mathrm{N}$ (Hersbach et al., 2020), the period of this study (roughly 2011-2017) has seen a continuation of the aforementioned trends. Over SV, NZ and FJ summer (June-August) surface air temperature was higher by ca. $0.5-1.0^{\circ} \mathrm{C}$ than over the reference period 1981-2010 (Fig. 2a). Most land areas also experienced slightly increased winter (September-May) precipitation by ca. 50-100 mm, or ca. 10-20 \% (Fig. 2b). In March the sea ice concentration decline was most apparent along the western coast of NZ and around SV (Fig. 2c), whereas in September north and east off FJ (Fig. 2d). ERA5 reanalysis presented by Morris et al. (2020) for the same period 2011-2017 indicates a strong increase in June-August sea surface temperature (by ca. $2^{\circ} \mathrm{C}$; period of reference 2004-2008) around SV and NZ, accompanied by June-August sea ice concentration drop along eastern coasts of the three study regions. 


\subsection{Glaciers of Svalbard, Novaya Zemlya and Franz Josef Land}

All three archipelagos of the Barents Sea are heavily glacier covered. The best-studied region is SV, hosting $34,000 \mathrm{~km}^{2}$ of land ice, mainly on its largest islands: mountainous Spitsbergen and more gentle Nordaustlandet and Edgeøya. According to the Randolph Glacier Inventory (RGI) v6.0 (Pfeffer et al., 2014), approximately $85 \%$ of the glacier population are mountain glaciers, which comprise $14 \%$ of the total ice area. Overall, glaciers of SV are known to lose mass over many past decades, recently at $-8 \mathrm{Gt} \mathrm{a}^{-1}$, equivalent to ca. $-0.23 \mathrm{~m}$ w.e. $\mathrm{a}^{-1}$ (2000-2019, Schuler et al., 2020). Larger glaciers of SV are typically polythermal, with a temperate base and cold surface layer, whereas small glaciers are predominantly cold, possibly with only

90 patches of temperate bed (Hagen et al., 1993; Sevestre et al., 2015). Thus, mountain glaciers display low ice velocities, typically on the order of 1-15 $\mathrm{m} \mathrm{a}^{-1}$ horizontally (e.g. Nutall and Hodgkins, 2005; Hambrey et al., 2005; Małecki, 2014). Such slowflowing glaciers exhibit also low emergence/submergence velocities, up to ca. $0.2 \mathrm{~m} \mathrm{a}^{-1}$, indicating that their elevation changes result primarily from surface processes, rather than ice dynamics (Melvold and Hagen, 1998; Hagen et al., 2005).

NZ comprises two main mountainous parts, Yuzhny Island and Severny Island. On the southern Yuzhny Island, only mountain glaciers are found, whereas the northern Severny Island is occupied by a large ice cap drained by outlet glaciers entering valleys or fjords, with a few independent mountain glaciers and an overall ice area of $22,000 \mathrm{~km}^{2}$. Mountain glaciers comprise $82 \%$ of the population and occupy $7 \%$ of the glacier area. FJ is a group of smaller islands covered nearly exclusively by marine-terminating ice caps, so small land-terminating glaciers (or ice caps' sectors) are sporadic ( $24 \%$ of the total number or $4 \%$ of ice area). The total ice area in FJ is ca. 13,000 $\mathrm{km}^{2}$. Based on the climatic conditions it may be assumed that small ice masses of NZ and FJ are cold-based and, therefore, slow-flowing, comparably to those in SV. Previous remote sensing investigations revealed NZ and FJ have been losing ice over the past decades. This mass loss accelerated post-2010 to $-14 \mathrm{Gt}$ $\mathrm{a}^{-1}$ (or $-0.68 \mathrm{~m}$ w.e.) and $-4 \mathrm{Gt} \mathrm{a}^{-1}$ (or $-0.35 \mathrm{~m}$ w.e.), respectively for $\mathrm{NZ}$ and FJ (Ciracì et al., 2018; Zheng et al., 2018), although not much is known about the state of mountain glaciers due to the scarcity of studies dedicated to this class of ice masses.

\section{Methods}

\section{3.1 Glacier selection, outlines and regionalisation}

Within each of the study regions additional subregions were distinguished, five, two and two, respectively for SV, NZ and FJ, all comprising between two and five sites. Overall, mountain glaciers at 29 sites were analysed: 19 sites in SV, 6 in NZ and 4 in FJ. The choice of individual study sites is a compromise between scientific interest and data availability.

For this study only small (from ca. 0.5 to ca. $30 \mathrm{~km}^{2}$ ) land-terminating glaciers were selected for the analysis to keep

110 comparability. The 382 selected glaciers, covering in total $1373 \mathrm{~km}^{2}$, represent the dominant type of small ice masses at a given site, e.g. niche, cirque and valley glaciers in western SV and NZ, small outlet glaciers or lobes of small ice caps in eastern $\mathrm{SV}$ and $\mathrm{FJ}$. 

date of the later digital elevation model used to assess glacier elevation changes. Therefore, glacier elevation change analysis does not consider areas deglaciated over the study period, which was preferred so that realistic glacier elevation change rates could be measured close to their margins. Ice divides were typically taken from RGI v6.0 (Pfeffer et al., 2014) unless contour lines generated from recent high-resolution data suggested their considerably different course. In such cases, ice divides were manually mapped. For the purpose of calculation of various glacier change parameters, areas of individual elevation bins were measured with a prescribed uncertainty of $10 \%$ and summed up to obtain the total glacier area at each site.

\subsection{Digital elevation models}

The basis of glacier elevation change analysis were high-resolution $(2 \mathrm{~m})$ digital elevation model (DEM) strips downloaded from the ArcticDEM repository. These DEMs were automatically generated from optical satellite images at a resolution of $\sim 0.5 \mathrm{~m}$ (WorldView), supported by ground control points obtained from ICE-Sat2 laser altimetry data, and provide elevations above the ellipsoid (Noh and Howat, 2015). ArcticDEM data are a useful tool in glacier monitoring and were previously successfully utilized in various glaciological applications (e.g. Barr et al. 2018; Zheng et al., 2018; Błaszczyk et al., 2019; Szafraniec and Dobiński, 2020; Holmlund, 2020; Elagina et al., 2021). However, its data suffer from several problems, making their use in glacier elevation change analysis challenging over some areas. Adding to a spectrum of issues common in glacier DEM comparisons (e.g. misalignments in $x, y$ and $z$ axes, reduced elevation data quality over snow-covered areas due to low contrast on satellite images etc.), ArcticDEMs render problems related to numerous artefacts (i.e. erroneously-generated random landforms), data gaps and temporal coverage (e.g. local shortages of quality DEMs for summer seasons). Solutions used to address these issues are described further in this section.

All DEMs used in this study were constructed from summer imagery (June-September) to minimize the impact of winter snow cover evolution on actual glacier surface elevation changes. The majority of source stereo-imagery was acquired between 2011 and 2017 and individual DEM pairs cover periods spanning from 3 to 7 years. At two locations in central SV (Sites 12 and 13), however, the Norwegian Polar Institute (NPI) 5 m DEMs valid for 2009 (NPI, 2014) were used as a reference due to the general scarcity of summer ArcticDEMs at these locations. This introduced a mismatch between the ellipsoid height of ArcticDEM and the orthometric height of NPI DEMs. To remedy this, the ArcticDEM data were converted to orthometric elevations using the EGM2008 geoid model (Pavlis et al., 2012), which at these concrete locations fits well the difference between the ellipsoid and orthometric heights. A list of all DEMs used in this study can be found in the supplementary data (Tab. S1).

\subsection{DEM differencing}

The majority of the 2-metre DEM pairs were misaligned against each other on the order of several metres in all dimensions and the co-registration technique by Nuth and Kääb (2011) was introduced to align the datasets. In some cases, however, this 
145 procedure was improved manually, since numerous data gaps and random artefacts reduced the usefulness of automatic coregistration. Alignment of DEMs was followed by subtraction of the older DEM from the more recent one to measure elevation change or elevation difference $(d h)$ over the study period. The resulting rasters of $d h$ (DEMs of Differences, DoDs) were further inspected for biases with the use of test polygons located on stable, gentle surfaces with no detected artefacts (e.g. roche moutonnée, inactive outwash fans, gentle slopes, near-coast lowlands etc.). Each DEM pair was covered with 4 - 10 test polygons, all having equal area (ranging from $\sim 80,000$ to $\sim 2,000,000 \mathrm{~m}^{2}$, depending on the site) and distributed across entire areas of interest. Within the polygons, average $d h$ was calculated and added/subtracted from DoDs, depending on the sign of bias. The standard deviation of elevation differences within test polygons was further used for uncertainty assessment of $d h$ measurement (see Sect. 3.8).

\subsection{Artifacts removal}

155 The artefacts on glacier surfaces were manually digitised as polygons in two steps. Hillshades of all DEMs were visually inspected for suspicious landforms (e.g. steep bumps, hollows, ridges or gullies on otherwise gentle glacier surfaces), whereas DoDs for unlikely patterns of glacier surface change (e.g. sharply defined areas of abnormally high or low $d h$ ). The artefact polygons were subsequently erased from DoDs. In certain situations the resulting data gaps on glaciers were larger than areas with useful data, making some DoDs heavily fragmented and only part of investigated glaciers have good data coverage.

\subsection{Quantification of glacier geodetic balance}

Due to the fragmentation of DoDs, the geodetic balance of glaciers at each site $(\overline{d h} / d t)$ was quantified by collecting all available $d h$ data within individual $50 \mathrm{~m}$ elevation bins and their integration with overall glacier hypsometry. To obtain elevations of each DoDs' cell and the general glacier area-altitude distribution, 10-metre resolution ArcticDEM mosaics were used. The mosaics are nearly complete DEMs of the Arctic constructed from the optimal ArcticDEM strips available for each area, therefore representing the surface at an unknown time, most likely at some point between 2011 and 2017. The mosaics were downsampled to $20 \mathrm{~m}$ with bilinear interpolation and corrected for ellipsoid with the EGM2008 geoid model (Pavlis et al., 2012). This geoid model matches the difference between the ellipsoid and orthometric heights within a few meter tolerance over the study regions, which is sufficient to plot the calculated glacier elevation change against altitude.

To improve computation efficiency, de-biased and de-artefacted DoDs at 2-metre resolution were downsampled and fit to a

$17020 \mathrm{~m}$ grid common with the downsampled ArcticDEM mosaics, using bilinear interpolation. All cells containing $d h$ information over glaciers were exported to a spreadsheet format, together with their respective orthometric elevations, and aggregated into $50 \mathrm{~m}$ elevation bins. Statistics of elevation changes were calculated for all bins and comprise medians, arithmetic means, standard deviations, $5^{\text {th }}, 10^{\text {th }}, 25^{\text {th }}, 75^{\text {th }}, 90^{\text {th }}$ and $95^{\text {th }}$ percentiles, which can be found in the supplementary data (Tabs. S2-S30).

Overall glacier hypsometry for each site was calculated from glacier outlines and the downsampled ArcticDEM mosaics corrected for the ellipsoid. Instead of using averaged values of $d h$ within each bin, their medians were used since these proved 

were subsequently multiplied by bin areas to obtain zonal volume change. Finally, overall glacier volume change within each site was divided by the total area of local glaciers to obtain site-wide elevation change and further recalculated to obtain annual rates, thus obtaining $\overline{d h} / d t$.

\subsection{Conversion of elevation changes to mass balance}

Conversion of $\overline{d h} / d t$ to mass balance ( $B$, given in metres of water equivalent, $\mathrm{m}$ w.e.) is typically performed by applying a fixed density to the overall $\overline{d h} / d t$ since this approach cancels the dynamic component of elevation changes of glaciers. However, Huss (2013) advised great caution when using this conversion method for studies of glacier change over periods of just several years and when glaciers are close to balance. For this reason, a different attempt was used in this study.

Because glaciers studied in this paper are small and are expected to display very low horizontal and vertical ice velocities, i.e. metres per year and centimetres per year, respectively, local thinning or thickening is assumed to roughly reflect point mass balances. For this reason, the conversion was performed for individual elevation bins at each site, rather than for overall glacier areas, and further integrated over the whole hypsometry to obtain $B$. It was assumed that bins dominated by surface lowering

190 are losing ice at a density of $890 \pm 20 \mathrm{~kg} \mathrm{~m}^{-3}$, whereas those dominated by elevation gains are considered as firn build-up at $550 \pm 50 \mathrm{~kg} \mathrm{~m}^{-3}$.

\subsection{Approximation of glacier volume change rates}

To approximate ice volume within individual sites, an empirical scaling by Martín-Español et al. (2015) was used, developed based on radar soundings of glaciers in SV. Volumes $\left(V\right.$, in $\left.\mathrm{km}^{3}\right)$ of all glaciers used in this study were calculated using their

195 areas $\left(A\right.$, in $\left.\mathrm{km}^{2}\right)$ and the 'logmse' scaling law:

$V=0.0343 \cdot A^{1.329}$,

(1)

Subsequently, all glacier volumes were summed up to obtain the total ice volume for each site. Errors of volumes obtained by scaling might be large for individual glaciers, as well as for samples of hundreds (Farinotti and Huss, 2013), so a conservative

200 uncertainty of the total site-specific $V$ approximation is set at $\pm 50 \%$. The overall $V$ at the sites was then used to calculate relative volume change rates $(\overline{d v} / d t)$ based on $\overline{d h} / d t$.

\subsection{Uncertainties}

Uncertainties of $d h$ calculated by DEM differencing are largely related to the quality of DEMs and the sample size used, but in this study, another important factor is at play. Overall, $804 \mathrm{~km}^{2}$ of glacier ice was investigated, equalling $59 \%$ of the total area of the study glaciers $\left(1373 \mathrm{~km}^{2}\right)$. No DoD used has complete data coverage for the local population of glaciers, which 

from surveyed to unsurveyed areas.

Considering above, it was assumed that uncertainties of elevation changes $(\varepsilon)$ measured for individual elevation bins are a function of: (i) the standard deviations of elevation differences within test polygons on low-relief stable ground $(\sigma)$,

210 representing the uncertainty of $d h$ measurement of a single cell; (ii) the total area surveyed within each elevation bin in $\mathrm{km}^{2}$ representing the sample size $(N)$ after Nuth et al. (2007); and (iii) the percentage of the unsurveyed area of each bin $\left(A_{u}\right)$, so that bins with low coverage have higher uncertainty.

$\varepsilon=\frac{1.5 \sigma}{\sqrt{N}} \cdot\left(1+A_{u}\right)$,

(2)

215 The multiplicator 1.5 in (2) aims to account for potentially lower quality of elevation data of ice and snow surfaces due to their lower contrast on satellite images. In cases where the lowest and/or highest bins of the local glacier population had no sufficient data to calculate reliable statistics (less than 100 cells), $d h$ data from the nearest useful bin were used instead, but with doubled uncertainty. Alternatively, missing elevation bins located in the middle of glaciers were approximated for $d h$ by averaging statistics from two neighbouring bins. Having the uncertainties of $d h$ for each elevation bin, uncertainties for other derived glacier change parameters were calculated by conventional error propagation techniques.

\section{Results}

The results of DEM differencing are summarized in Tab. 1 and Figs. 3, 4 and 5. For detailed information for each site see the supplementary data, i.e. statistics (Tabs. S1-S30) and figures (relationships between elevation change and altitude in Figs. S1S29 and maps in Figs. S30-S42).

\subsection{Svalbard}

SV contains the largest population of mountain glaciers across the European Arctic. The most negative $\overline{d h} / d t$ was found in SV-W (Fig. 3a), where all elevation bins of glaciers have been experiencing thinning. Relationships between glacier elevation change and altitude were fairly coherent across this subregion (Fig. 4) so that the site-to-site variability in $\overline{d h} / d t$ (from -1.58 $\mathrm{m} \mathrm{a}^{-1}$ to $-0.87 \mathrm{~m} \mathrm{a}^{-1}$ ) resulted largely from hypsometry, here represented by median elevation (Tab. 1; Fig. 5). 
https://doi.org/10.5194/tc-2021-165

Preprint. Discussion started: 31 May 2021

(c) Author(s) 2021. CC BY 4.0 License.

Table 1 General statistics of glacier geometry, elevation change, mass balance and volume change across the study sites (for site locations see Fig. 3).

\begin{tabular}{|c|c|c|c|c|c|c|c|c|c|c|c|c|c|}
\hline $\begin{array}{l}\text { Region } \\
\text { and } \\
\text { subregion }\end{array}$ & $\begin{array}{c}\text { Site } \\
\text { number }\end{array}$ & Site name & $\begin{array}{c}\text { Total } \\
\text { area of } \\
\text { the study } \\
\text { glaciers } \\
{\left[\mathrm{km}^{2}\right]}\end{array}$ & $\begin{array}{c}\text { Glacier } \\
\text { area } \\
\text { surveyed } \\
{[\%]}\end{array}$ & $\begin{array}{c}\begin{array}{c}\text { Median } \\
\text { elevation }\end{array} \\
\text { of the } \\
\text { study } \\
\text { glaciers } \\
{[\mathrm{m}]}\end{array}$ & $\begin{array}{c}\text { Date of earlier } \\
\text { DEM }\end{array}$ & $\begin{array}{c}\text { Date of later } \\
\text { DEM }\end{array}$ & $\begin{array}{c}\text { Standard } \\
\text { deviation of } \\
\text { DEM elevation } \\
\text { differences on } \\
\text { test polygons, } \\
\sigma \\
{[\mathrm{m}]}\end{array}$ & $\begin{array}{c}\text { Geodetic } \\
\text { balance, } \\
\overline{d h} / d t \\
{\left[\mathrm{~m} \mathrm{a}^{-1}\right]}\end{array}$ & $\begin{array}{c}\text { Total } \\
\text { area of } \\
\text { elevation } \\
\text { bins with } \\
\text { positive } \\
\text { change } \\
{[\%]}\end{array}$ & $\begin{array}{c}\begin{array}{c}\text { Mass } \\
\text { balance, } \\
\boldsymbol{B}\end{array} \\
\text { [m w.e. } \mathrm{a}^{-1} \text { ] }\end{array}$ & $\begin{array}{c}\begin{array}{c}\text { Relative } \\
\text { volume }\end{array} \\
\text { change rate, } \\
\overline{d v} / d t \\
{\left[\% \mathrm{a}^{-1}\right]}\end{array}$ & $\begin{array}{c}\text { Approximate time } \\
\text { of complete decay } \\
\text { assuming constant } \\
\text { relative volume } \\
\text { change rate }\end{array}$ \\
\hline \multicolumn{14}{|l|}{ Svalbard } \\
\hline SV-W & 3 & Prins Karls Forland & 15 & 61 & 174 & $2011 / 07 / 15$ & $2017 / 08 / 02$ & 1.07 & $-1.58 \pm 0.16$ & 0 & $-1.40 \pm 0.14$ & $-3.91 \pm 1.99$ & 2040 's \\
\hline SV-W & 4 & Grønfjorden & 53 & 92 & 295 & $2013 / 08 / 17$ & $2016 / 07 / 25$ & 0.75 & $-1.17 \pm 0.09$ & 0 & $-1.05 \pm 0.08$ & $-1.85 \pm 0.93$ & 2070's \\
\hline SV-W & 5 & Van Keulenfjorden & 78 & 57 & 445 & $2013 / 07 / 30$ & $2016 / 07 / 26$ & 0.56 & $-0.87 \pm 0.13$ & 0 & $-0.77 \pm 0.11$ & $-0.93 \pm 0.48$ & early-22nd century \\
\hline SV-W & 6 & Nottinghambukta & 37 & 62 & 360 & $2013 / 07 / 30$ & $2016 / 07 / 26$ & 0.75 & $-1.05 \pm 0.19$ & 0 & $-0.93 \pm 0.17$ & $-1.18 \pm 0.62$ & early-22nd century \\
\hline SV-W & 7 & Sørkapp & 45 & 87 & 248 & $2013 / 08 / 11$ & $2017 / 08 / 03$ & 0.39 & $-1.49 \pm 0.08$ & 0 & $-1.33 \pm 0.07$ & $-1.95 \pm 0.98$ & 2060 's \\
\hline SV-E & 8 & Edgeøya South & 39 & 95 & 278 & $2012 / 08 / 08$ & $2017 / 07 / 21$ & 0.59 & $-1.56 \pm 0.09$ & 0 & $-1.39 \pm 0.08$ & $-3.01 \pm 1.51$ & 2050's \\
\hline SV-C & 12 & Nordenskiöld Land & 51 & 57 & 591 & Early-July 2009 & $2013 / 07 / 17$ & 0.65 & $-0.37 \pm 0.07$ & 0 & $-0.33 \pm 0.07$ & $-0.64 \pm 0.34$ & late-22nd century \\
\hline SV-C & 13 & Dickson Land & 48 & 74 & 497 & Early-July 2009 & $2013 / 07 / 17$ & 0.93 & $-0.57 \pm 0.08$ & $\sim 0$ & $-0.50 \pm 0.07$ & $-0.95 \pm 0.49$ & early-22nd century \\
\hline SV-C & 14 & Atomfjella & 107 & 43 & 784 & $2013 / 09 / 01$ & $2017 / 09 / 10$ & 0.61 & $-0.17 \pm 0.07$ & 43 & $-0.16 \pm 0.04$ & $-0.19 \pm 0.12$ & post-22nd century \\
\hline SV-C & 15 & Vestfjorden & 90 & 23 & 769 & $2011 / 06 / 15$ & $2016 / 07 / 02$ & 0.71 & $-0.10 \pm 0.11$ & 43 & $-0.11 \pm 0.07$ & $-0.16 \pm 0.18$ & post-22nd century \\
\hline SV-N & 16 & Primatesfjella & 61 & 62 & 403 & $2012 / 08 / 15$ & $2017 / 07 / 10$ & 0.77 & $0.26 \pm 0.06$ & 85 & $0.14 \pm 0.03$ & $0.46 \pm 0.25$ & $\mathrm{n} / \mathrm{a}$ \\
\hline SV-N & 17 & Andrée Land & 112 & 57 & 480 & $2012 / 07 / 07$ & $2017 / 07 / 31$ & 0.65 & $0.08 \pm 0.04$ & 81 & $0.03 \pm 0.02$ & $0.14 \pm 0.10$ & $\mathrm{n} / \mathrm{a}$ \\
\hline SV-N & 18 & Laponiahalvøya & 14 & 43 & 229 & $2012 / 06 / 15$ & $2017 / 08 / 06$ & 0.58 & $-0.18 \pm 0.12$ & 39 & $-0.17 \pm 0.09$ & $-0.41 \pm 0.35$ & post-22nd century \\
\hline SV-N & 19 & Platenhalvøya & 11 & 72 & 172 & $2013 / 07 / 13$ & $2017 / 07 / 23$ & 0.68 & $-0.14 \pm 0.15$ & 38 & $-0.14 \pm 0.10$ & $-0.23 \pm 0.27$ & post-22nd century \\
\hline \multicolumn{14}{|l|}{ Novaya } \\
\hline \multicolumn{14}{|l|}{ Zemlya } \\
\hline NZ-S & 20 & Yuzhny Island & 53 & 53 & 569 & $2013 / 06 / 18$ & $2016 / 06 / 17$ & 0.44 & $-1.23 \pm 0.09$ & 0 & $-1.09 \pm 0.08$ & $-1.76 \pm 0.89$ & 2070's \\
\hline NZ-S & 21 & Rusanov Valley & 48 & 40 & 471 & $2009 / 07 / 26$ & $2016 / 08 / 17$ & 0.65 & $-1.27 \pm 0.09$ & 0 & $-1.13 \pm 0.08$ & $-2.17 \pm 1.10$ & 2060's \\
\hline FJ-SW & 27 & Markham Sound & 27 & 84 & 152 & $2013 / 07 / 19$ & $2017 / 07 / 18$ & 0.37 & $-0.47 \pm 0.04$ & 0 & $-0.42 \pm 0.04$ & $-1.10 \pm 0.56$ & early-22nd century \\
\hline FJ-NE & 28 & Wilczek Land & 10 & 76 & 299 & $2013 / 07 / 19$ & $2017 / 07 / 18$ & 0.62 & $-0.17 \pm 0.11$ & 8 & $-0.15 \pm 0.09$ & $-0.29 \pm 0.24$ & post-22nd century \\
\hline FJ-NE & 29 & Jackson Island & 20 & 73 & 118 & $2013 / 08 / 29$ & $2017 / 08 / 13$ & 0.76 & $-0.03 \pm 0.11$ & 55 & $-0.04 \pm 0.09$ & $-0.05 \pm 0.19$ & post- 22 nd century \\
\hline
\end{tabular}

In SV-E thinning was also glacier-wide, supported by a relatively low hypsometry of local populations of mountain glaciers.

240 From the available data, a northward trend of less negative elevation changes is visible. Glacier $\overline{d h} / d t$ ranged from $-1.56 \mathrm{~m}$ $\mathrm{a}^{-1}$ in the south to $-0.58 \mathrm{~m} \mathrm{a}^{-1}$ in the north. 

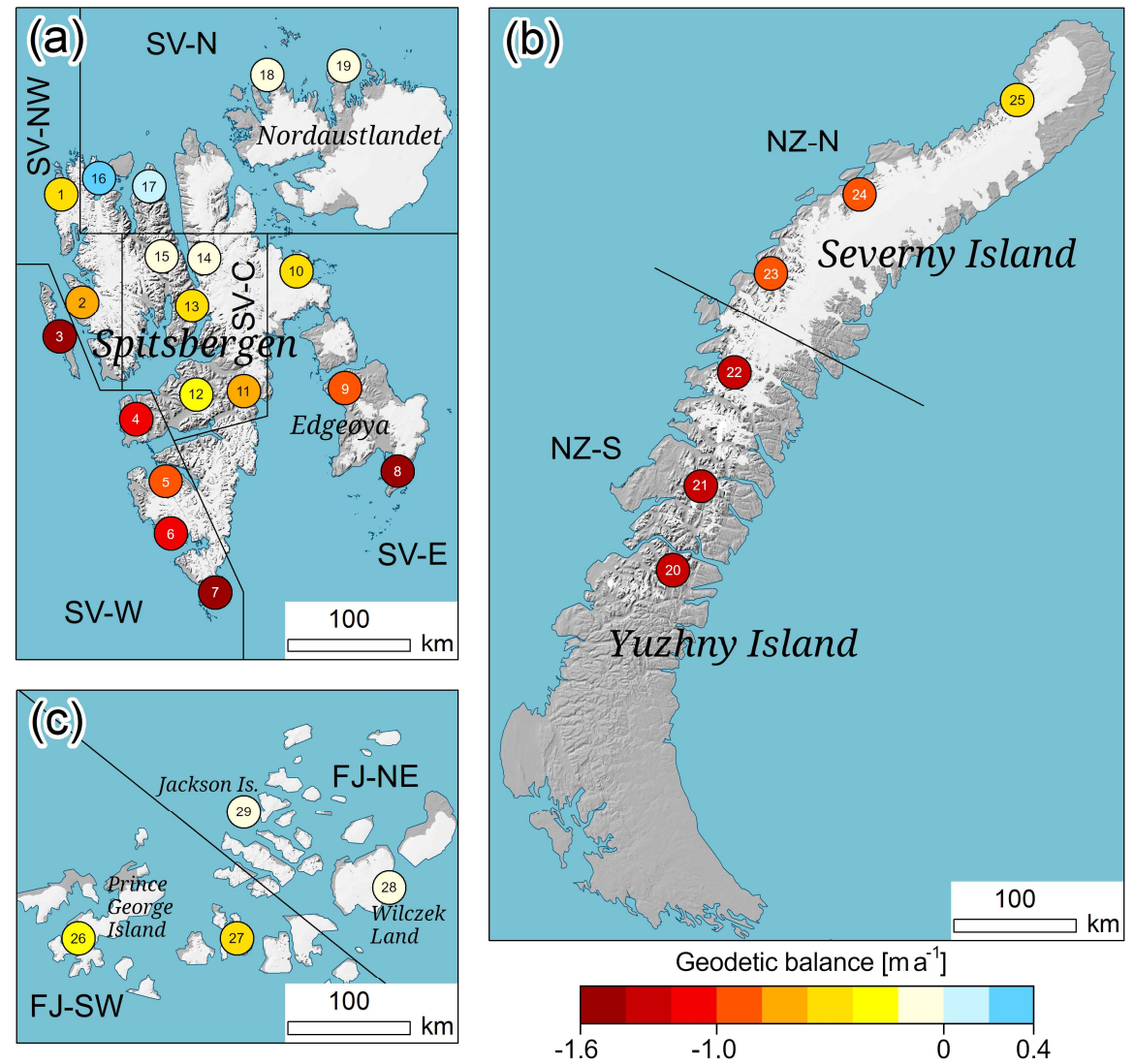

Figure 3 Geodetic balance of mountain glaciers for subregions and sites on (a) Svalbard, (b) Novaya Zemlya and (c) Franz Josef Land. Numbers in circles indicate individual study sites (see Tab. 1 for more details). For site-specific maps and details see the supplementary data. Topographic background: hillshaded ArcticDEM.

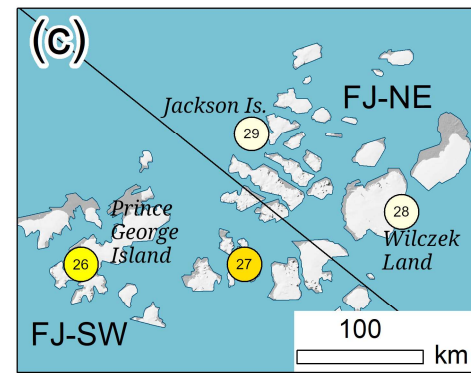

The subregion containing the highest-elevated ice masses presented in this study is SV-C. These showed positive $d h$ only above ca. $900 \mathrm{~m}$ a.s.l., so many glaciers not exceeding this altitude have been thinning in all elevation bins. Despite the highest area-altitude distribution, mountain glaciers of SV-C have been generally losing mass, with $\overline{d h} / d t$ spanning from $-0.78 \mathrm{~m} \mathrm{a}^{-1}$ to $-0.10 \mathrm{~m} \mathrm{a}^{-1}$ between individual sites, strongly correlated with glacier median elevations (Tab. 1; Fig. 5).

In SV-N mountain glaciers displayed a contrasting pattern of change. Over the period of study, local glaciers have been experiencing positive $d h$ above 225-360 m a.s.l. Overall, glaciers in SV-N were close to geodetic equilibrium or even thickened. Glacier $\overline{d h} / d t$ at four sites ranged from -0.18 to $-0.14 \mathrm{~m} \mathrm{a}^{-1}$ in north Nordaustlandet to 0.08 to $0.26 \mathrm{~m} \mathrm{a}^{-1}$ in north Spitsbergen. 
The subregion SV-NW might be considered a transition zone between fast ice losses of SV-W and balanced conditions of SV$\mathrm{N}$, with a probable poleward gradient reducing glacier thinning rates. Both sites in SV-NW showed a thickening trend above ca. $480-600 \mathrm{~m}$ a.s.1., but otherwise negative $\overline{d h} / d t$ of -0.62 and $-0.41 \mathrm{~m} \mathrm{a}^{-1}$.
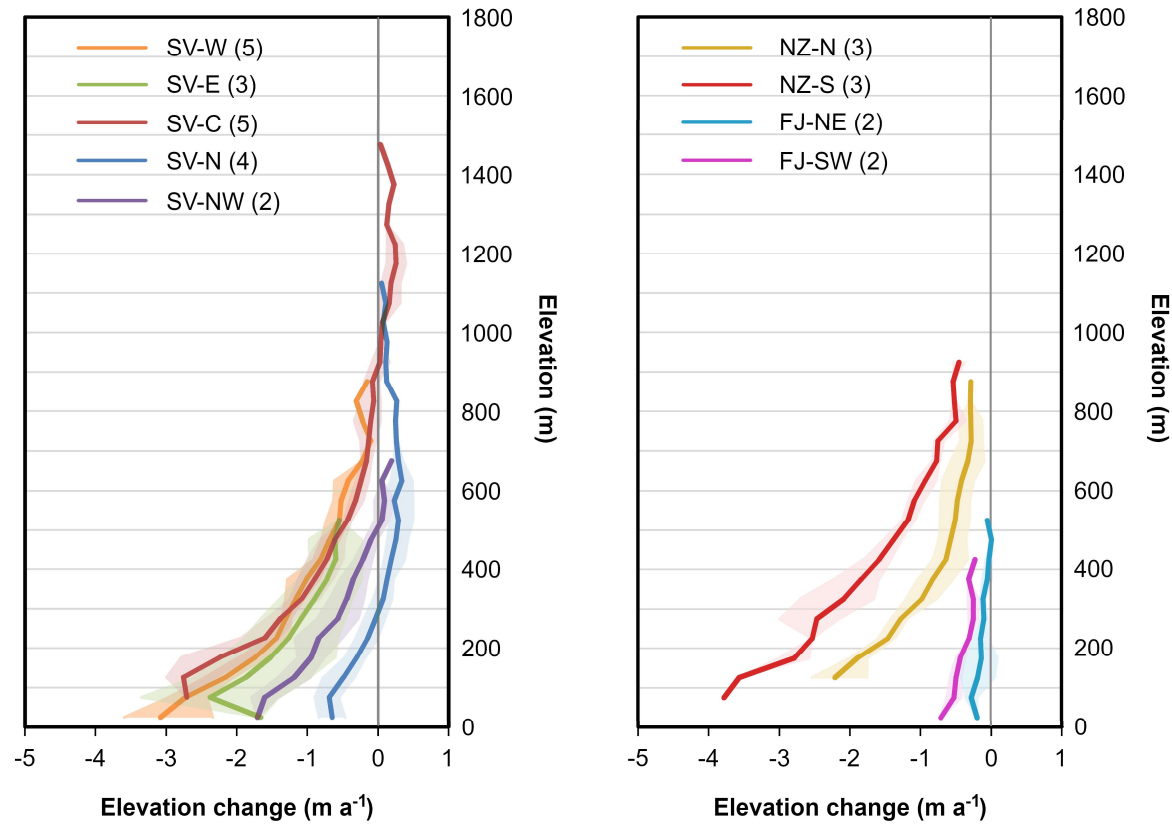

Figure 4 Relationships between glacier elevation change and altitude averaged over subregions. Numbers in parentheses denote the number of sites within each subregion, while shading indicates minimum and maximum elevation change values at a given altitude within each subregion. For site-specific glacier elevation change curves and glacier hypsometry, see the supplementary data.

\subsection{Novaya Zemlya}

260 In the subregion NZ-N, three sites of mountain glaciers were analysed. All of them showed glacier-wide thinning with an apparent northward trend of less negative $\overline{d h} / d t$, ranging from $-0.87 \mathrm{~m} \mathrm{a}^{-1}$ to $-0.49 \mathrm{~m} \mathrm{a}^{-1}$. Three sites comprising the other subregion, NZ-S, displayed very high rates of glacier-wide mass loss, with $\overline{d h} / d t$ between $-1.28 \mathrm{~m} \mathrm{a}^{-1}$ and $-1.23 \mathrm{~m} \mathrm{a}^{-1}$ (Fig. 3b), enhanced by rapid marginal thinning (Fig. 4).

\subsection{Franz Josef Land}

265 The FJ region is characterized by the lowest topography and extensive coverage of large ice caps on most islands. For these reasons, the region contains the fewest mountain glaciers, so to collect sufficient data, some ice masses analysed here were small land-terminating ice caps or their gentle lobes, rather than cirque or valley glaciers. In general, two sites of small glaciers 

$\mathrm{m} \mathrm{a}^{-1}$ (Figs. 3c and 4).

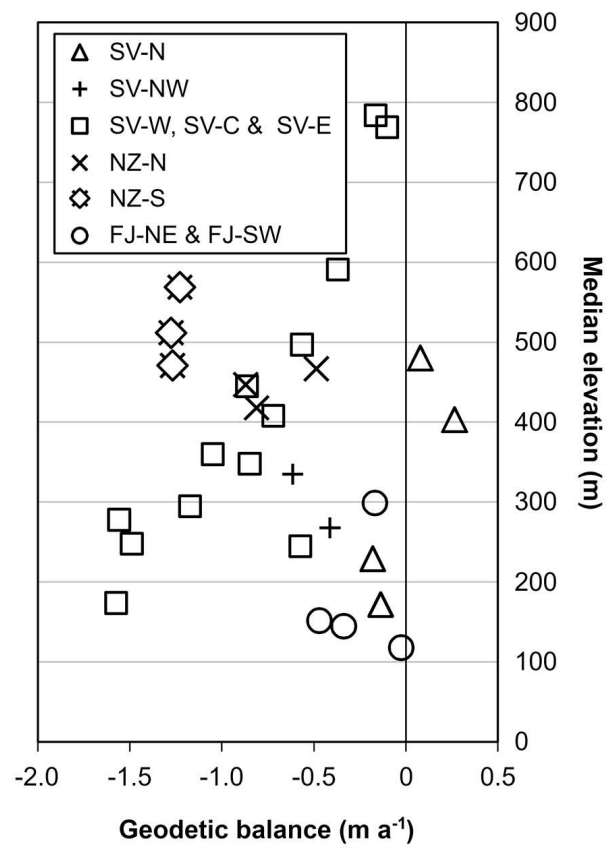

Figure 5 Relationships between geodetic balances of glaciers for individual sites and their median elevations.

\section{Discussion}

\subsection{Comparison with other studies}

The glacier change trends described in this study are in general agreement with previously published data for several areas in $\mathrm{SV}$, which indicate mass loss from smaller glaciers and their common high-elevation thinning (Kohler et al., 2007; James et al., 2012; Małecki, 2016; Sobota et al., 2016; Elagina et al., 2021). Negative trends of change of small glaciers can be seen also in NZ (Ciracì et al., 2018) and FJ (Zheng et al., 2018). The recently published global atlas of glacier elevation changes at $100 \mathrm{~m}$ resolution by Hugonnet et al. (2021) shows a comparable spatial pattern of $\overline{d h} / d t$ across the regions investigated here. However, within the glacier boundaries used in this study, the changes calculated by Hugonnet et al. (2021) for the period 2010-2019 were on average less negative by ca. $0.4 \mathrm{~m} \mathrm{a}^{-1}$ for sites experiencing $\overline{d h} / d t<-1.0 \mathrm{~m} \mathrm{a}^{-1}$ and by ca. $0.1 \mathrm{~m} \mathrm{a}^{-1}$ more negative for sites displaying balanced conditions ( sites with $\overline{d h} / d t>-0.2 \mathrm{~m} \mathrm{a}^{-1}$ ). This discrepancy might be linked to several 
factors, e.g. lower resolution of the global study and other differences in methodologies (input data, periods of observation, etc.), the relative contribution of which is difficult to quantify.

\subsection{Spatial variability of glacier change}

Over the study period, mountain glaciers across the European Arctic have been generally losing mass. On a regional scale, the fastest rates of mass loss were observed in NZ, while these were modest in FJ. The median $B$ calculated from data in Tab. 1 was $-0.51 \mathrm{~m}$ w.e. for sites in SV, $-0.93 \mathrm{~m}$ w.e. for $\mathrm{NZ}$ and $-0.23 \mathrm{~m}$ w.e. for FJ. Application of these median values to $\sim 4600$ $\mathrm{km}^{2}$ covered in total by mountain glaciers in SV, $\sim 1600 \mathrm{~km}^{2}$ in NZ and $\sim 550 \mathrm{~km}^{2}$ in FJ (RGI v6.0, Pfeffer et al., 2014) yields rough estimates of their relative contributions to total mass balances of individual regions. These were ca. $25 \%, 10 \%$ and 2

$\%$, respectively, if taking the recently published totals of $-8 \mathrm{Gt} \mathrm{a}^{-1}$ (or $-0.23 \mathrm{~m}$ w.e.) for SV, $-14 \mathrm{Gt} \mathrm{a}^{-1}$ (or $-0.64 \mathrm{~m}$ w.e.) for NZ and $-4 \mathrm{Gt} \mathrm{a}^{-1}$ (or $-0.35 \mathrm{~m}$ w.e.) for FJ (Schuler et al., 2020; Ciracì et al., 2018; Zheng et al., 2018).

Comparison of $B$ reported in Tab. 1 against the regional totals summarized above highlights the generally faster melting of the small ice masses. Ice losses were particularly strong along western Spitsbergen (SV-W), Edgeøya (part of SV-E) and NZ (NZ$\mathrm{S}$ and NZ-N). This partly correlates with the general trajectory of atlantic currents (Fig. 1a), recent strong warming of the sea surface (Morris et al., 2020) and, to some extent, with a sharp reduction of winter sea ice concentration (Fig. 2c). This suggests that the aforementioned processes of Atlantification contribute to changes of land-terminating glaciers on islands surrounding the Barents Sea, but this would require further testing.

The greatest spatial variability of $\overline{d h} / d t$ was found in SV. Two overlapping gradients reducing glacier thinning rates are evident from Fig. 3a. The northward trend results in a shift towards less negative/more positive $\overline{d h} / d t$ in SV-N, which could

300 be explained by the generally cooler climatic conditions of the north SV (e.g. Hanssen-Bauer et al., 2019). The other interior ward gradient reduces elevation losses in SV-C. However, the relationships between glacier thinning and altitude were remarkably consistent between SV-W, SV-C and partly SV-E (Fig. 4), so at a common elevation their thinning rates have been similar (Fig. S42) and close to zero just at ca. $900 \mathrm{~m}$ a.s.l. This implies that over this vast portion of SV (SV-W, SV-C and SVE) it was predominantly elevation that controlled the spatial variability of $\overline{d h} / d t$ of mountain glaciers (Fig. 5), rather than climatic differences, e.g. associated with the distance to the open sea. In NZ a clear northward gradient of less negative $\overline{d h} / d t$ was also found, whereas in FJ $\overline{d h} / d t$ was more homogenous, although also with a possible slight north-eastward trend reducing the thinning rates (Figs. $3 b$ and $3 c$ ).

\subsection{Glacier-wide thinning}

From all 29 investigated sites, as many as 21 have been experiencing substantial thinning $\left(\overline{d h} / d t<-0.20 \mathrm{~m} \mathrm{a}^{-1}\right)$. At 19 of these

310 sites, negative $d h$ was observed even in the highest elevations (Tab. 1). This glacier-wide thinning is apparent in all study regions and as such might be regarded as the dominant style of the response of mountain glaciers to recent climatic conditions across the Barents Sea area. 

glacier-wide thinning suggests that many of these glaciers might eventually melt away completely even without further warming. Recent $\overline{d v} / d t$ across all regions was on average close to $-1 \% \mathrm{a}^{-1}$, but some subregions have been experiencing far more negative $\overline{d v} / d t$, particularly SV-W, SV-E and NZ-S, where some sites displayed severe losses of 2-4 \% $\mathrm{a}^{-1}$ (Tab. 1). Assuming a continuation of the observed $\overline{d v} / d t$ into the future, mountain glaciers might disappear from many study sites within the coming two to five decades, whereas glaciers in the majority of the sites might vanish within about 100 years (Tab. 1). Although the glacier changes were inferred for a relatively short period and the assumption of constant $\overline{d v} / d t$ oversimplifies the processes behind glacier and climate evolution, the numbers provided above are still indicative of the critical state of mountain glaciers at many sites in SV and NZ. The ultimate disappearance of mountain glaciers will shift individual valleys or entire subregions from glacierized to ice-free, e.g. large parts of SV-C or NZ-S. This might have a large impact on the landscape, fjord systems, land hydrology and ecology, among others (e.g. Milner et al., 2017; Huss and Hock, 2018; Strzelecki et al., 2018; 2020; Cauvy-Fraunié and Dangles, 2019; Torsvik et al., 2019; Hopwood et al., 2020).

\subsection{The North Spitsbergen anomaly}

Despite the recent strong warming trend across the Barents Sea and the generally rapid ice loss among its mountain glaciers, eight sites analyzed here had $\overline{d h} / d t>-0.20 \mathrm{~m} \mathrm{a}^{-1}$. All of these were restricted to the north-eastern rims of SV (SV-N and north part of SV-C) and FJ (FJ-NE). At two of these sites in north Spitsbergen (Sites 16 and 17) glaciers even gained mass over the study period (Fig. 3a; Tab. 1; Figs. S16, S17, S37).

330 The duration of the north Spitsbergen anomaly remains unclear at this point, however, previously collected data suggest this might be a relatively recent phenomenon. Positive $\overline{d h} / d t$ and $B$ over the study period was accompanied by a slight retreat of glacier margins at Sites 16 and 17, while an earlier direct study from this area by Etzelmüller et al. (1993) reported a clearly negative $B$ for one glacier at Site 16 between 1970 and the 1990s. These facts suggest that the mass gain reported in this paper resulted from a post-1990 climate forcing, acting on a shorter timescale than the reaction time of glaciers. A recent global

335 study of glacier elevation changes by Hugonnet et al. (2021) suggests that mountain glaciers in north Spitsbergen have been relatively close to balance since at least the early-2000's.

Accounting for the presupposed low ice dynamics of the study glaciers, the reported glacier thickening suggests strong gradients in mass balance forcing over short distances, i.e. from west (e.g. Sites 3, 2 and 1) to north Spitsbergen (Sites 16 and 17). One hypothetical explanation of the anomaly might be the recent rapid retreat of winter sea ice off north SV (Onarheim

340 et al., 2014), potentially favouring more snowfall over SV-N. Such phenomenon is, however, not evident from the global-scale ERA5 reanalysis presented in Fig. 2, which shows that SV-N did experience strong sea ice retreat and a slight increase in winter precipitation, but comparably to some other subregions where fast glacier mass loss was observed, e.g. SV-E and NZN. Outcomes of a finer-scale $500 \mathrm{~m}$ climate model by Noël et al. (2020) neither do match the observations reported here and show generally negative trends in $B$ over Sites 16 and 17. This highlights the need for even higher-resolution dedicated models 

climate models' accuracy. Ideally, direct monitoring of glaciers in north Spitsbergen should be considered to implement, since this area is underrepresented in the Svalbard-wide glaciological studies (Schuler et al., 2020), thus likely biasing the surface mass balance measurements towards regions with faster mass losses.

\section{Conclusions}

350 This study used high-resolution elevation data (ArcticDEM) to investigate recent (ca. 2011-2017) elevation changes and mass balance of 382 small (< ca. $30 \mathrm{~km}^{2}$ ) land-terminating glaciers (or mountain glaciers) across the European High Arctic and documents spatially variable patterns of their change. The vast majority of the study glaciers has been experiencing considerable thinning, at several sites exceeding the rate of $1.0 \mathrm{~m} \mathrm{a}^{-1}$, particularly in SV-W, partly SV-E and NZ-S. Glacierwide thinning has been the dominant style of response to strong climate warming over the Barents Sea area. Since elevation changes of the study glaciers are expected to be driven primarily by surface processes, strong elevation losses at high elevations indicate negative mass balance in their former accumulation zones. This implies that many of these small ice masses might melt away even at present climate, regardless of future climate change mitigation efforts and climate warming rates. Under hypothetical constant volume loss rates reported in this study, many sites in SV and NZ would nearly completely lose mountain glaciers within the coming half-century, underlining their critical imbalance with the recent climate.

Despite the overwhelming dominance of negative changes across arctic Europe, mountain glaciers at some of the northernmost sites, i.e. in subregions SV-N and FJ-NE, have been remaining close to equilibrium over the period of study. Furthermore, north Spitsbergen (part of SV-N) was the only detected spot that experienced positive changes. The nature of this anomaly requires further investigation, particularly because the SV region has been experiencing one of the most severe climate warming rates over the past half-century globally. This finding highlights the complexity of climate-glacier interactions even for low-activity small ice masses and the possibility of very contrasting glacier changes over relatively short distances. The results of this research might be a useful benchmark for the validation of climate models and point to the need for careful site selection when choosing representative glaciers for direct monitoring.

\section{Data availability}

The ArcticDEM digital elevation model strips and mosaics are available via the ArcticDEM repository https://www.pgc.umn.edu/data/arcticdem/. The ERA5 reanalysis datasets are available via the Copernicus programme https://cds.climate.copernicus.eu/cdsapp\#!/search?type=dataset. Glacier elevation change data developed for this study is available upon request from the author. 


\section{Competing interests}

The author declares no competing interests.

\section{References}

Årthun, M., Eldevik, T., Smedsrud, L. H., Skagseth, Ø., and Ingvaldsen, R. B.: Quantifying the influence of atlantic heat on Barents Sea ice variability and retreat, J. Climate, 25, 4736-4743, https://doi.org/10.1175/JCLI-D-11-00466.1, 2012.

Barr, I., Dokukin, M., Kougkoulos, I., Livingstone, S., Lovell, H., Małecki, J., and Muraviev, A.: Using ArcticDEM to analyse the dimensions and dynamics of debris-covered glaciers in Kamchatka, Russia, Geosciences, 8, 216, 380 https://doi.org/10.3390/geosciences8060216, 2018.

Barton, B. I., Lenn, Y., and Lique, C.: Observed Atlantification of the Barents Sea causes the polar front to limit the expansion of winter sea ice, J. Phys. Oceanogr., 48, 1849-1866, https://doi.org/10.1175/JPO-D-18-0003.1, 2018.

Błaszczyk, M., Ignatiuk, D., Grabiec, M., Kolondra, L., Laska, M., Decaux, L., Jania, J., Berthier, E., Luks, B., Barzycka, B., and Czapla, M.: Quality assessment and glaciological applications of digital elevation models derived from space-borne and

385 aerial images over two tidewater glaciers of southern Spitsbergen, Rem. Sens., 11, 1121. http://dx.doi.org/10.3390/rs11091121, 2019.

Box, J. E., Colgan, W. T., Wouters, B., Burgess, D.,O’Neel, S., Thomson, L. I., and Mernild, S. H.: Global sea-level contribution from Arctic land ice: 1971-2017, Environ. Res. Lett., 13, 125012, https://doi.org/10.1088/1748-9326/aaf2ed, 2018.

390 Cauvy-Fraunié, S., and Dangles, O.: A global synthesis of biodiversity responses to glacier retreat, Nature Ecology \& Evolution, 3, 1675-1685, https://doi.org/10.1038/s41559-019-1042-8, 2019.

Ciracì, E., Velicogna, I., and Sutterley, T.: Mass Balance of Novaya Zemlya archipelago, Russian High Arctic, using timevariable gravity from GRACE and altimetry data from ICEsat and Cryosat-2, Rem. Sens., 10, 1817, http://dx.doi.org/10.3390/rs10111817, 2018.

395 Comiso, J.C., and Hall, D.K.: Climate trends in the Arctic as observed from space, WIREs Clim. Change, 5, 389-409, https://doi.org/10.1002/wcc. $277,2014$.

Dahlke, S., Hughes, N. E., Wagner, P. M., Gerland, S., Wawrzyniak, T., Ivanov, B., and Maturlii, M.: The observed recent surface air temperature development across Svalbard and concurring footprints in local sea ice cover, Int. J. Climatol., 40, 5246- 5265. https://doi.org/10.1002/joc.6517, 2020. 

Grønfjordbreen, Svalbard, 2006-2020, estimated by glaciological, geodetic and modeling approaches, Geosciences, 11, 78, http://dx.doi.org/10.3390/geosciences11020078, 2021.

Etzelmüller, B., Vatne, G., Ødegârd, R. S., and Sollid J. L.: Mass balance and changes of surface slope, crevasse and flow pattern of Erikbreen, northern Spitsbergen: an application of a geographical information system (GIS), Polar Res., 12:2, 131146, https://doi.org/10.3402/polar.v12i2.6709, 1993.

Farinotti, D. and Huss, M.: An upper-bound estimate for the accuracy of glacier volume-area scaling, Cryosphere, 7, 17071720, https://doi.org/10.5194/tc-7-1707-2013, 2013.

Farinotti, D., Huss, M., Fürst, J. J., Landmann, J., Machguth, H., Maussion, F., and Pandit, A.: A consensus estimate for the ice thickness distribution of all glaciers on Earth, Nat. Geosci., 12, 168-173, https://doi.org/10.1038/s41561-019-0300-3, 2019.

Hagen, J. O., Liestøl, O., Roland, E., and Jørgensen, T. Glacier atlas of Svalbard and Jan Mayen. Oslo, Norwegian Polar Institute, 1993.

Hagen, J., Eiken, T., Kohler, J., and Melvold, K.: Geometry changes on Svalbard glaciers: mass-balance or dynamic response?, Ann. Glaciol., 42, 255-261, https://doi.org/10.3189/172756405781812763, 2005.

415 Hambrey, M. J., Murray, T., Glasser, N. F., Hubbard, A., Hubbard, B., Stuart, G., Hansen, S., and Kohler, J.: Structure and changing dynamics of a polythermal valley glacier on a centennial timescale: Midre Lovénbreen, Svalbard, J. Geophys. Res., 110, F01006, https://doi.org/10.1029/2004JF000128, 2005.

Hanssen-Bauer, I., Førland, E., Hisdal, H., Mayer, S., Sandø, A., and Sorteberg, A. (eds.): Climate in Svalbard 2100 - a knowledge base for climate adaptation, Norwegian Environment Agency (Miljødirektoratet), Oslo, 2019.

Hersbach, H., Bell, B., Berrisford, P., Hirahara, S., Horányi, A., Muñoz-Sabater, J., Nicolas, J., Peubey, C., Radu, R., Schepers, D., Simmons, A., Soci, C., Abdalla, S., Abellan, X., Balsamo, G., Bechtold, P., Biavati, G., Bidlot, J., Bonavita, M., De Chiara, G., Dahlgren, P., Dee, D., Diamantakis, M., Dragani, R., Flemming, J., Forbes, R., Fuentes, M., Geer, A., Haimberger, L., Healy, S., Hogan, R. J., Hólm, E., Janisková, M., Keeley, S., Laloyaux, P., Lopez, P., Lupu, C., Radnoti, G., de Rosnay, P., Rozum, I., Vamborg, F., Villaume, S., and Thépaut J.-N.: The ERA5 global reanalysis. Q. J. Roy. Meteor. Soc., 146, 19992049, https://doi.org/10.1002/qj.3803, 2020.

Holmlund, E.: Aldegondabreen glacier change since 1910 from structure-from-motion photogrammetry of archived terrestrial and aerial photographs: Utility of a historic archive to obtain century-scale Svalbard glacier mass losses, J. Glaciol., 67, 107116, https://doi.org/10.1017/jog.2020.89, 2020. 
Hopwood, M. J., Carroll, D., Dunse, T., Hodson, A., Holding, J. M., Iriarte, J. L., Ribeiro, S., Achterberg, E. P., Cantoni, C., Carlson, D. F., Chierici, M., Clarke, J. S., Cozzi, S., Fransson, A., Juul-Pedersen, T., Winding, M. H. S., and Meire, L.: Review article: How does glacier discharge affect marine biogeochemistry and primary production in the Arctic?, Cryosphere, 14, 1347-1383, https://tc.copernicus.org/articles/14/1347/2020/, 2020.

Hugonnet, R., McNabb, R., Berthier, E., Menounos, B., Nuth, C., Girod, L., Farinotti, D., Huss, M., Dussaillant, I., Brun, F., and Kääb, A.: Accelerated global glacier mass loss in the early twenty-first century, Nature, 592, 726-731, https://doi.org/10.1038/s41586-021-03436-z, 2021.

Huss, M.: Density assumptions for converting geodetic glacier volume change to mass change, Cryosphere, 7, 877-887, https://doi.org/10.5194/tc-7-877-2013, 2013.

Huss, M., and Hock, R.: Global-scale hydrological response to future glacier mass loss, Nature, 8, 135-140, https://doi.org/10.1038/s41558-017-0049-x, 2018.

Isaksen, K., Nordli, Ø., Førland, E. J., Łupikasza, E., Eastwood, S., and Niedźwiedź, T.: Recent warming on SpitsbergenInfluence of atmospheric circulation and sea ice cover, J. Geophys. Res.-Atmos., 121, 11913- 11931, https://doi.org/10.1002/2016JD025606, 2016.

James, T. D., Murray, T., Barrand, N. E., Sykes, H. J., Fox, A. J., and King, M. A.: Observations of enhanced thinning in the upper reaches of Svalbard glaciers, Cryosphere, 6, 1369-1381, https://doi.org/10.5194/tc-6-1369-2012, 2012.

Kohler, J., James, T. D., Murray, T., Nuth, C., Brandt, O., Barrand, N. E., Aas, H.F., and Luckman A.: Acceleration in thinning rate on western Svalbard glaciers. Geophys. Res. Lett., 34, L18502, https://doi.org/10.1029/2007GL030681, 2007.

Kohnemann, S. H. E., Heinemann, G., Bromwich, D. H., and Gutjahr, O.: Extreme warming in the Kara Sea and Barents Sea during the winter period 2000-16, J. Climate, 30, 8913-8927, https://doi.org/10.1175/JCLI-D-16-0693.1, 2017.

Lind, S., Ingvaldsen, R.B., and Furevik, T.: Arctic warming hotspot in the northern Barents Sea linked to declining sea-ice import, Nat. Clim. Change, 8, 634-639, https://doi.org/10.1038/s41558-018-0205-y, 2018.

Małecki, J.: Some comments on the flow velocity and thinning of Svenbreen, Dickson Land, Svalbard, Czech Polar Rep., 4 , $1-8,2014$

Małecki, J.: Accelerating retreat and high-elevation thinning of glaciers in central Spitsbergen, Cryosphere, 10, 1317-1329, https://doi.org/10.5194/tc-10-1317-2016, 2016.

455 Martín-Español, A., Navarro, F., Otero, J., Lapazaran, J., and Błaszczyk, M.: Estimate of the total volume of Svalbard glaciers, and their potential contribution to sea-level rise, using new regionally based scaling relationships, J. Glaciol., 61, 29-41, https://doi.org/10.3189/2015JoG14J159, 2015. 
Melvold, K., and Hagen, J. O.: Evolution of a surge-type glacier in its quiescent phase: Kongsvegen, Spitsbergen, 1964-95, J. Glaciol., 44, 394-404, https://doi.org/10.3189/S0022143000002720, 1998.

Milner, A. M., Khamis, K., Battin, T. J., Brittain, J. E., Barrand, N. E., Füreder, L., Cauvy-Fraunié, S., Gíslason, G. M., Jacobsen, D., Hannah, D. M., Hodson, A. J., Hood, E., Lencioni, V., Ólafsson, J. S., Robinson, C. T., Tranter, M., and Brown, L. E.: Glacier shrinkage driving global changes in downstream systems, PNAS, 114, 9770-9778, https://doi.org/10.1073/pnas.1619807114, 2017

Moholdt, G., Wouters, B., and Gardner, A. S.: Recent mass changes of glaciers in the Russian High Arctic, Geophys. Res. Lett., 39, L10502, https://doi.org/10.1029/2012GL051466, 2012.

Morris, A., Moholdt, G., and Gray, L.: Spread of Svalbard glacier mass loss to Barents Sea margins revealed by CryoSat-2, J. Geophys. Res.-Earth, 125, e2019JF005357, https://doi.org/10.1029/2019JF005357, 2020.

Noël, B., van de Berg, W. J., Lhermitte, S., Wouters, B., Schaffer, N., and van den Broeke, M. R.: Six decades of glacial mass loss in the Canadian Arctic Archipelago, J. Geophys. Res.-Earth, 123, 1430- 1449, https://doi.org/10.1029/2017JF004304, 2018.

Noël, B., Jakobs, C. L., van Pelt, W. J. J., Lhermite, S., Wouters, B., Kohler, J., Hagen, J. O., Luks, B., Reijmer, C. H., van de Berg, W. J., van den Broeke, M. R.: Low elevation of Svalbard glaciers drives high mass loss variability, Nat. Commun., 11, 4597, https://doi.org/10.1038/s41467-020-18356-1, 2020.

Noh, M.-J., and Howat, I. M.: Automated stereo-photogrammetric DEM generation at high latitudes: Surface Extraction with TIN-based Search-space Minimization (SETSM) validation and demonstration over glaciated regions, GISci. Remote Sens., 52, 198-217, https://doi.org/10.1080/15481603.2015.1008621, 2015.

Nordli, Ø., Wyszyński, P., Gjelten, H. M., Isaksen, K., Łupikasza, E., Niedźwiedź, T., and Przybylak, R.: Revisiting the extended Svalbard Airport monthly temperature series, and the compiled corresponding daily series 1898-2018, Polar Res., 39, 3614, https://doi.org/10.33265/polar.v39.3614, 2020.

480 NPI: Terrengmodell Svalbard (S0 Terrengmodell) [Data set]. Norwegian Polar Institute. https://doi.org/10.21334/npolar.2014.dce53a47, 2014.

Nuth, C., and Kääb, A.: Co-registration and bias corrections of satellite elevation data sets for quantifying glacier thickness change, Cryosphere, 5, 271-290, https://doi.org/10.5194/tc-5-271-2011, 2011

Nuth, C., Kohler, J., Aas, H., Brandt, O., and Hagen, J.: Glacier geometry and elevation changes on Svalbard (1936-90): A baseline dataset, Ann. Glaciol., 46, 106-116, https://doi.org/10.3189/172756407782871440, 2007.

Nuttall, A., and Hodgkins, R.: Temporal variations in flow velocity at Finsterwalderbreen, a Svalbard surge-type glacier, Ann. Glaciol., 42, 71-76, https://doi.org/10.3189/172756405781813140, 2005. 
Onarheim, I. H., Smedsrud, L. H., Ingvaldsen, R. B., and Nilsen, F.: Loss of sea ice during winter north of Svalbard, Tellus A, 66, https://doi.org/10.3402/tellusa.v66.23933, 2014.

490 Pavlis, N. K., Holmes, S. A., Kenyon, S. C., and Factor, J. K.: The development and evaluation of the Earth Gravitational Model 2008 (EGM2008), J. Geophys. Res., 117, B04406, https://doi.org/10.1029/2011JB008916, 2012.

Pfeffer, W. T., Arendt, A. A., Bliss, A., Bolch, T., Cogley, J. G., Gardner, A. S., Hagen, J.-O., Hock, R., Kaser, G., Kienholz, C., Miles, E. S., Moholdt, G., Mölg, N., Paul, F., Radić, V., Rastner, P., Raup, B. H., Rich, J. and Sharp, M. J.: The Randolph Glacier Inventory: a globally complete inventory of glaciers, J. Glaciol., 60, 537-552, https://doi.org/10.3189/2014JoG13J176, 2014.

Piechura, J., and Walczowski, W.: Warming of the West Spitsbergen Current and sea ice north of Svalbard, Oceanologia, 51, 147-164, 2009.

Schuler, T. V., Kohler, J., Elagina, N., Hagen, J. O. M., Hodson, A. J., Jania, J. A., Kääb, A. M., Luks, B., Małecki, J., Moholdt, G., Pohjola, V. A., Sobota, I., Van Pelt, W. J. J.: Reconciling Svalbard Glacier Mass Balance, Front. Earth Sci., 8, 500 https://doi.org/10.3389/feart.2020.00156, 2020.

Screen, J., and Simmonds, I.: The central role of diminishing sea ice in recent Arctic temperature amplification, Nature, 464, 1334-1337, https://doi.org/10.1038/nature09051, 2010.

Sevestre, H., Benn, D. I., Hulton, N. R. J., and Bælum, K.: Thermal structure of Svalbard glaciers and implications for thermal switch models of glacier surging, J. Geophys. Res.-Earth, 120, 2220-2236, https://doi.org/10.1002/2015JF003517, 2015.

505 Sobota, I., Nowak, M., and Weckwerth, P.: Long-term changes of glaciers in north-western Spitsbergen, Global Planet. Change, 144, 182-197, https://doi.org/10.1016/j.gloplacha.2016.07.006, 2016.

Strzelecki, M. C., Long, A. J., Lloyd, J. M., Małecki, J., Zagórski, P., Pawłowski, Ł., Jaskólski, M. W.: The role of rapid glacier retreat and landscape transformation in controlling the post-Little Ice Age evolution of paraglacial coasts in central Spitsbergen (Billefjorden, Svalbard), Land. Degrad. Dev., 29, 1962- 1978, https://doi.org/10.1002/ldr.2923, 2018.

510 Strzelecki, M. C., Szczuciński, W., Dominiczak, A., Zagórski, P., Dudek, J., and Knight, J.: New fjords, new coasts, new landscapes: The geomorphology of paraglacial coasts formed after recent glacier retreat in Brepollen (Hornsund, southern Svalbard), Earth Surf. Proc. Land., 45, 1325-1334, https://doi.org/10.1002/esp.4819, 2020.

Szafraniec, J. E., and Dobiński, W.: Deglaciation Rate of Selected Nunataks in Spitsbergen, Svalbard-Potential for Permafrost Expansion above the Glacial Environment, Geosciences, 10, https://doi.org/10.3390/geosciences10050202, 2020.

515 Torsvik, T., Albretsen, J., Sundfjord, A., Kohler, J., Sandvik, A. D., Skarðhamar, J., Lindbäck, K., Everett, A.: Impact of tidewater glacier retreat on the fjord system: Modeling present and future circulation in Kongsfjorden, Svalbard, Estuar. Coast. Shelf Sci., 220, 152-165, https://doi.org/10.1016/j.ecss.2019.02.005, 2019. 
https://doi.org/10.5194/tc-2021-165

Preprint. Discussion started: 31 May 2021

(c) Author(s) 2021. CC BY 4.0 License.

Walczowski, W. and Piechura, J.: Influence of the West Spitsbergen Current on the local climate, Int. J. Climatol., 31, 10881093, https://doi.org/10.1002/joc.2338, 2011.

520 Wawrzyniak, T. and Osuch, M.: A 40-year High Arctic climatological dataset of the Polish Polar Station Hornsund (SW Spitsbergen, Svalbard), Earth Syst. Sci. Data, 12, 805-815, https://doi.org/10.5194/essd-12-805-2020, 2020.

Wouters, B., Gardner, A. S., and Moholdt, G.: Global glacier mass loss during the GRACE satellite mission (2002-2016), Front. Earth Sci., 7, https://doi.org/10.3389/feart.2019.00096, 2019.

Zheng, W., Pritchard, M.E., Willis, M.J., Tepes, P., Gourmelen, N., Benham, T.J., and Dowdeswell, J.A.: Accelerating glacier

525 mass loss on Franz Josef Land, Russian Arctic, Remote Sens. Environ., 211, 357-375, https://doi.org/10.1016/j.rse.2018.04.004, 2018. 